\title{
Maternal Exposure of Low Dose of TCDD Modulates the Expression of Estrogen Receptor Subunits of Male Gonads in Offspring
}

\author{
Kenji OHYAMA $^{1)}$, Masanori OHTA ${ }^{1)}$, Tomoaki SANO ${ }^{1}$, Kazumasa SATO $^{1)}$, Yoshiko NAKAGOMI ${ }^{1}$, \\ Yoshie SHIMURA ${ }^{1)}$ and Yoshiaki YAMANO ${ }^{2) *}$ \\ ${ }^{1)}$ Interdisciplinary Graduate School of Medical and Engineering Sciences, University of Yamanashi, Yamanashi 409-3898 and \\ ${ }^{2)}$ Laboratory of Veterinary Biochemistry, Faculty of Agriculture, Tottori University, Tottori 680-8553, Japan
}

(Received 21 September 2006/Accepted 22 February 2007)

ABSTRACT. We have analyzed the effects of low-dose transplacental and lactational exposure of 2,3,7,8-tetrachlorodibenzo- $p$-dioxin (TCDD) on gene expression relating to the dioxin and sexual hormone cascade, and demonstrated the effects on testicular growth and sexual maturation in male offspring rats. TCDD $(10 \mathrm{ng} / \mathrm{kg})$ was administered to dams on Days 7 and 14 of gestation, and on Days 0 , 7 and 14 after delivery. Gene expression of cytochrome P450 family 1 subfamily A polypeptide 1 (CYP1A1) in the liver of 17-day-old rats was significantly increased compared with controls. Furthermore, expression of estrogen receptors (ER) $\alpha$ and ER $\beta$ was significantly increased at 17 and 42 days old, respectively in the testis of TCDD-administered rats compared with controls. Although testicular weight and the seminiferous tubule diameter were increased in 17-day-old rats, there was no difference in the number of germ cells between TCDD-treated and control animals. The expressions of androgen receptor and inhibin subunit genes were not significantly changed. These findings suggest that low-dose exposure of TCDD leads to unusual development of the testis by perturbation of steroid hormone homeostasis.

KEY WORDS: CYP1A1, estrogen receptor, gene expression, spermatogenesis, TCDD.

J. Vet. Med. Sci. 69(6): 619-625, 2007

TCDD is the most potent congener of the polychlorinated dioxins and is regarded as one of the important endocrine disruptors. Toxic effects of TCDD are mediated by the aryl hydrocarbon receptor (AhR) that binds TCDD with high affinity and heterodimerizes with the AhR nuclear translocator (ARNT) [7, 15, 24, 26, 34].

Maternal exposure to high dose of TCDD causes many irreversible abnormalities in various organs of fetus and offspring. Many researchers have reported that transplacental and lactational exposure to TCDD results in adverse changes to the male reproductive system $[1,2,6,11,16,17$, $28,32]$. Many of these studies, however, were conducted using relatively high doses of TCDD. The effects of lowdose TCDD exposure have been reported by Peterson et al. [25], Ohsako et al. [21], and others [6, 8, 13, 31]. The expression of AhR in rats was increased by low-dose TCDD administration [8], and apoptosis of tubular cells was induced following depression by follicle stimulating hormone (FSH) [30]. Significant reductions were detected in testicular weight, daily sperm production and sperm numbers after in utero exposure of male rats to a single low dose of TCDD [25]. Using the same study protocol, the amounts of TCDD transferred to offspring from dams were found to be proportional to the injected amounts of 12.5 to $800 \mathrm{ng} / \mathrm{kg}$, and furthermore, androgen receptor (AR) mRNA levels in the ventral prostate were decreased by the lowest dose of TCDD [21]. Faqi et al. [6] reported that treatment of dams with low doses of TCDD throughout pregnancy and lacta-

\footnotetext{
* Correspondence to: Yamano, Y., Laboratory of Veterinary Biochemistry, Faculty of Agriculture, Tottori University, Tottori 680-8553, Japan.
}

tion decreased the number of sperm and increased the number of abnormal sperm in offspring at puberty and adulthood. Conversely, several study groups reported that in utero exposure of high dose of TCDD did not reduce daily sperm production of rat offspring [35], and that testicular weight of offspring was not changed by subchronic in utero exposure [4]. Thus, the effects of maternal exposure of TCDD on testicular function of offspring remain controversial.

Since environmental exposure to TCDD is usually of a repeated persistent low-dose nature, the aim of this study is to examine effects on the offspring to maternal rats receiving comparable exposure. In the present study, we injected low-dose TCDD into pregnant rats, once per week, from fetal sex differentiation until they were weaned, and observed changes in gene expression in the testis and liver of male offspring.

\section{MATERIALS AND METHODS}

Animals: Seven pregnant Slc. Wistar rats were obtained on Day 3 of gestation (the day of sperm detection in vaginal smears was considered as Day 0). Dams were housed individually in an air-conditioned animal room at a temperature of $22^{\circ} \mathrm{C}$, relative humidity of $55 \pm 10 \%$, and a 12 -hr light/ 12-hr dark cycle. Animals received food and water ad libitum. Animal experiments using TCDD in this study were approved by the University of Yamanashi Animal Care and Use Committee.

TCDD administration to animals and morphology of the testis: TCDD (AccuStandard, Germany) was preserved in toluene solution $(1 \mathrm{mg} / \mathrm{m} l)$. The stock solution was finally 
made up to a concentration of $100 \mathrm{ng} \mathrm{TCDD} / \mathrm{m} l$ diluted in corn oil. Four of the dams were treated with TCDD and 3 controls were treated with vehicle of the same volume. TCDD was administered subcutaneously to dams at a dose of $10 \mathrm{ng} / \mathrm{kg}$ body weight $(0.02-0.03 \mathrm{ml} /$ injection) once per week (for a total of 5 times), on Days 7 and 14 of gestation and on Days 0, 7 and 14 after delivery. Offspring were weaned 21 days after birth, thereby terminating TCDD exposure from lactation. The 4 dams treated with TCDD delivered 42 offspring (17 males and 25 females) and the 3 controls delivered 34 offspring (16 males and 18 females). Randomly selected offspring were used for the following experiment. Nine male offspring from each of TCDDtreated group and control group were sacrificed at 17 days after birth, and others at 42 days after birth. External anomalies were examined, including anogenital distance and macroscopic organ anomalies. Body and right testicular weights were measured. The testis was examined histologically according to the procedure previously reported [23, 29].

Slices of testis were hematoxylin-eosin (H-E) stained. The numbers of germ cells per seminiferous tubule, Sertoli cells and Leydig cells were counted of stage XI at 42 days old, and the diameter of round seminiferous tubules (15 tubules per testis) at 17 and 42 days old were measured under a microscope.

Analysis of gene expression: Total RNA was isolated from the testis with Qiagen's RNeasy Mini Kit (Qiagen K.K. Japan). For amplification of the target genes, reversetranscription (RT) and polymerase chain reaction (PCR) were run in two separate steps. Briefly, equal amounts of total RNA $(1 \mu \mathrm{g})$ were used for RT in a final volume of 20 $\mu l$, containing avian myeloblastosis virus (AMV)-RT buffer, 5 U AMV-reverse transcriptase (RTase) (Takara
Co., Ltd., Japan), $20 \mathrm{U}$ ribonuclease inhibitor, $1 \mathrm{mM}$ dNTP mixture, and 50 pmol random hexamer primers. Reaction mixtures were incubated at $30^{\circ} \mathrm{C}$ for $10 \mathrm{~min}$, followed by $42^{\circ} \mathrm{C}$ for $30 \mathrm{~min}$, and finally heated at $97^{\circ} \mathrm{C}$ for $5 \mathrm{~min}$, to inactivate the RTase. The cDNA products were stored at $-20^{\circ} \mathrm{C}$ until use. Sequences and annealing temperatures of the primer sets are given in Table 1. The sequences of these primers were designed according to the DNA database. Accession numbers of these genes are as follows; CYP1A1: NM_012540, AhR: NM_013149, ARNT: NM_012780, inhibino: NM_012590, inhibin $\beta$-A: NM_017128, inhibin $\beta$ B: XM_001053684, ER $\alpha$ : NM_012689, ER $\beta$ : NM_012754, AR: NM_ 012502, glyceraldehyde 3-phosphate dehydrogenase (GAPDH): NM_017008. The cDNA in accordance with $100 \mathrm{ng}$ RNA was amplified in PCR buffer in the presence of $1.5 \mathrm{mM} \mathrm{MgCl}_{2}, 2.5 \mathrm{U}$ Taq DNA polymerase, 200 $\mathrm{nM}$ dNTP mixture, and $10 \mathrm{nM}$ each primer. PCR cycle conditions were as follows; the first denaturing cycle at $97^{\circ} \mathrm{C}$ for $5 \mathrm{~min}$, followed by a variable number of cycles of amplification defined by denaturation at $97^{\circ} \mathrm{C}$ for $0.5 \mathrm{~min}$, annealing of the primers to the cDNA at appropriate temperature (Table 1) for $1 \mathrm{~min}$, and fragment extension at $72^{\circ} \mathrm{C}$ for 1 min, with a final extension at $72^{\circ} \mathrm{C}$ for $7 \mathrm{~min}$. PCR conditions were applied in this exponential range for semi-quantitative analysis. Different cycles were tested for all genes to define the exponential range, and appropriate cycles were chosen for further analysis (data not shown).

PCR products were electrophoresed on a $1.5 \%$ agarose gel and visualized with ethidium bromide staining. Stained gels were placed on a UV transilluminator and recorded with a CCD camera. Images were examined using gel and blot analysis software (ImageGauge software, Fuji Film Co., Ltd., Japan). Values for specific target gene expression were standardized with those of the GAPDH gene as the

Table 1. Gene (cDNA) and species-specific primers and conditions used for RT-PCR analysis

\begin{tabular}{|c|c|c|c|}
\hline Gene (cDNA) & Primer sets & $\begin{array}{l}\text { nnealing } \\
\text { erature }\left({ }^{\circ} \mathrm{C}\right)\end{array}$ & Cycles \\
\hline \multirow[t]{2}{*}{ CYP1A1 } & CCATGACCAGGAACTATGGG & 60 & 28 \\
\hline & TCTGGTGAGCATCCAGGACA & & \\
\hline \multirow[t]{2}{*}{ AhR } & AGGGAGGTTAAAGTATCTTCATGGAC & 60 & 28 \\
\hline & TCCCTAGGTTTCTCATGATGCTATAC & & \\
\hline \multirow[t]{2}{*}{ ARNT } & CTTGGCTCTGTGAAGGAAGG & 60 & 28 \\
\hline & CGGAATCGGAACATGACAG & & \\
\hline \multirow[t]{2}{*}{ inhibin $\alpha$} & TTCATTTTCCACTACTGCCATGGTAGCT & 55 & 32 \\
\hline & GATACAAGCACAGTGTTGTGTAATGAG & & \\
\hline \multirow[t]{2}{*}{ inhibin $\beta$-A } & TCAACAGTCATTAACCACTACCGCATGA & 55 & 34 \\
\hline & AGCCACACTCCTCCACAATCATGTT & & \\
\hline \multirow[t]{2}{*}{ inhibin $\beta$-B } & AGGCAACAGTTCTTCATCGACTTTCGGCT & 55 & 30 \\
\hline & AGCCACACTCCTCCACAATCATGTT & & \\
\hline \multirow[t]{2}{*}{ ER $\alpha$} & AATTCTGACAATCGACGCCAG & 60 & 30 \\
\hline & GTGCTTCAACATTCTCCСТCСТC & & \\
\hline \multirow[t]{2}{*}{$\mathrm{ER} \beta$} & TTCCCGGCAGCACCAGTAACC & 60 & 34 \\
\hline & TCCCTCTTTGCGTTTGGACTA & & \\
\hline \multirow[t]{2}{*}{ AR } & CCCATCGACTATTACTTCCCACC & 60 & 28 \\
\hline & TTCTCCTTCTTCCTGTAGTTTGA & & \\
\hline \multirow[t]{2}{*}{ GAPDH } & CCCTCAAGATTGTCAGCAATGC & 55 & 24 \\
\hline & GTCCTCAGTGTAGCCCAGGAT & & \\
\hline
\end{tabular}


internal standard.

Statistical analysis: Results are presented as means \pm SE. Statistical significance was determined by Student's $t$-test using StatView-J 5.0 software.

\section{RESULTS}

Body and testicular weight and size of seminiferous tubules: Body weight was significantly lighter in TCDDtreated rats than in controls at 42 days old $(\mathrm{p}<0.01)$. Testicular weight was heavier at those 17 days old and lighter at 42 days old in TCDD-treated rats compared to control rats $(p<0.01)$. The ratio of the testicular weight to body weight was also significantly heavier at 17 days in TCDD-treated rats $(\mathrm{p}<0.01$, data not shown). Morphological examination of testis revealed that seminiferous tubule diameter was significantly greater at 17 days in TCDD-treated rats compared with those of controls $(p<0.01)$ (Table 2). Microscopic observation revealed no significant differences in the numbers of germ cells, Sertoli cells and Leydig cells between TCDD-treated and control rats at either 17 or 42 days (Fig. $1)$.

Expression of CYP1A1,AhR and ARNT in the liver and testis: CYP1A1 mRNA expression was not observed in the testis of TCDD-treated or control rats at either 17 or 42 days. However, TCDD-treated rats showed a dramatic increase in expression in the liver at 17 days. Compared with control, expression was greater by 10 -fold at 17 days and 3 -fold at 42 days in the liver of TCDD-treated rats. However, expression of AhR and ARNT mRNA was decreased in the liver of TCDD-treated rats at 42 days compared with controls (Fig. 2).

Expression of steroid receptors: Expression of steroid receptors in the testis of control rats changed with age between 17 days and 42 days. ER $\alpha$ mRNA expression was increased while $\mathrm{ER} \beta \mathrm{mRNA}$ expression was decreased at 42 days. The level of ER $\alpha$ mRNA expression was significantly greater at 17 days in the testis of TCDD-treated rats compared with controls $(\mathrm{p}<0.01)$. There was no significant difference in ER $\alpha$ expression in the testis at 42 days between TCDD-treated rats and controls. ER $\beta$ expression was greater at 42 days in the testis of TCDD-treated rats, but not at 17 days compared with the control group. TCDD treatment did not alter the level of testicular AR mRNA expression at either 17 or 42 days old (Fig. 3).

Expression of inhibin subunits in the testis: Inhibina and
$\beta$-A mRNA expression in the testis of controls decreased with age between 17 and 42 days old. TCDD treatment did not alter the expression of inhibin $\alpha, \beta$-A and $\beta$-B mRNA at either 17 or 42 days old (Fig. 4).

\section{DISCUSSION}

In the present study, we examined the effects of low dose transplacental and lactational exposure of TCDD to male offspring rats. Usually, dams are injected with an initial loading dose of TCDD and a weekly maintenance dose of one fifth of this amount to provide a constant drug concentration in the body, and Faqi et al. [6] and Ikeda et al. [12] examined the effects of TCDD on male offspring under these conditions. In our experiment, however, $10 \mathrm{ng} / \mathrm{kg}$ of TCDD was subcutaneously administered to pregnant rats once per week, for a total of 5 times, from gestational Day 7 , and reproductive toxicity was evaluated in male offspring. We calculated the deposited TCDD concentration in each dam, as more than $30 \mathrm{ng} / \mathrm{kg}$ at the final TCDD treatment without consideration of lactational excretion, since it is known that the half-life of TCDD in rats is 2 to 3 weeks [33]. As Nishimura et al. [19] demonstrated with the transfoster experiment, TCDD concentration in serum was more than 10-fold higher in the breast milk-fed group compared with the transplacental-exposed group. Male offspring used in this study were mainly exposed to TCDD from breast milk. Before evaluating the effects of TCDD on the male reproductive system, we first determined CYP1A1 expression in the liver.

We observed that the expression of CYP1A1 mRNA was markedly increased in the liver of TCDD-treated offspring aged 17 days ( 3 days after final TCDD administration to maternal rats), and increased even in offspring aged 42 days (28 days after final TCDD administration). The reason for the decrease in the expression of AhR and ARNT mRNA in the liver of TCDD-treated rats at 42 days is uncertain at this point. We used TCDD-administrated male rats to evaluate the testicular development and steroid hormone receptor gene expression in relation to low-dose TCDD exposure.

Interestingly, testicular weight was significantly heavier and the ratio of the testicular weight to body weight was significantly greater at 17 days in TCDD-treated rats. Histological examination revealed that, seminiferous tubule diameter was increased in TCDD-treated offspring at 17 days, although there was no difference in the number of

Table 2. The effect of maternal exposure of TCDD on growth and testicular development of male rat offspring

\begin{tabular}{lcccc}
\hline & \multicolumn{2}{c}{17 days } & \multicolumn{2}{c}{42 days } \\
& $\begin{array}{c}\text { Control } \\
(\mathrm{n}=9)\end{array}$ & $\begin{array}{c}\text { TCDD } \\
(\mathrm{n}=9)\end{array}$ & $\begin{array}{c}\text { Control } \\
(\mathrm{n}=8)\end{array}$ & $\begin{array}{c}\text { TCDD } \\
(\mathrm{n}=7)\end{array}$ \\
\hline $\begin{array}{l}\text { Body weight }(\mathrm{g}) \\
\begin{array}{l}\text { Testicular* } \\
\text { weight }(\mathrm{mg})\end{array}\end{array}$ & $22.2 \pm 0.8$ & $23.6 \pm 1.2$ & $130.0 \pm 2.0$ & $112.9 \pm 7.9^{\# \#}$ \\
$\begin{array}{l}\text { Diameter } \\
\text { of tubules }(\mu \mathrm{m})\end{array}$ & $92.0 \pm 3.1$ & $68.8 \pm 5.7^{\text {\#\# }}$ & $726.0 \pm 58.9$ & $597.3 \pm 54.8^{\# \#}$ \\
\hline
\end{tabular}

* Right testicular weight is shown. \#\#: $\mathrm{p}<0.01$. 


\section{Control}

$17 \mathrm{D}$

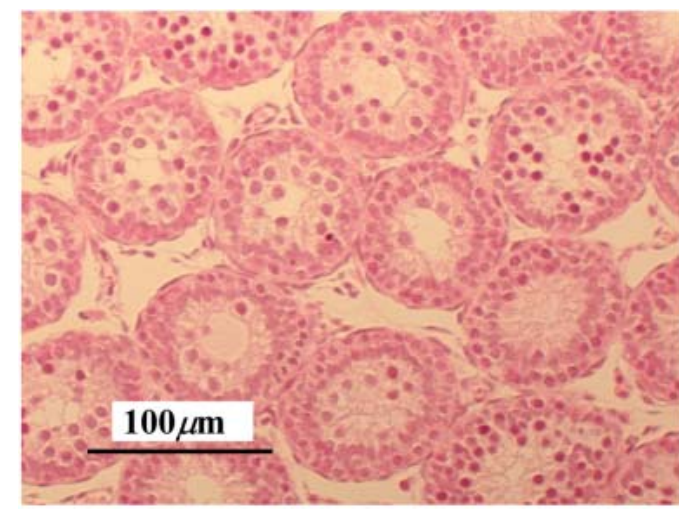

$42 \mathrm{D}$

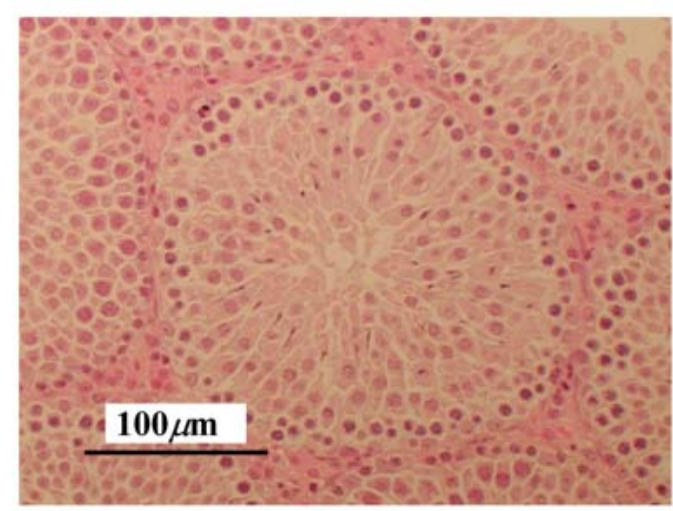

TCDD
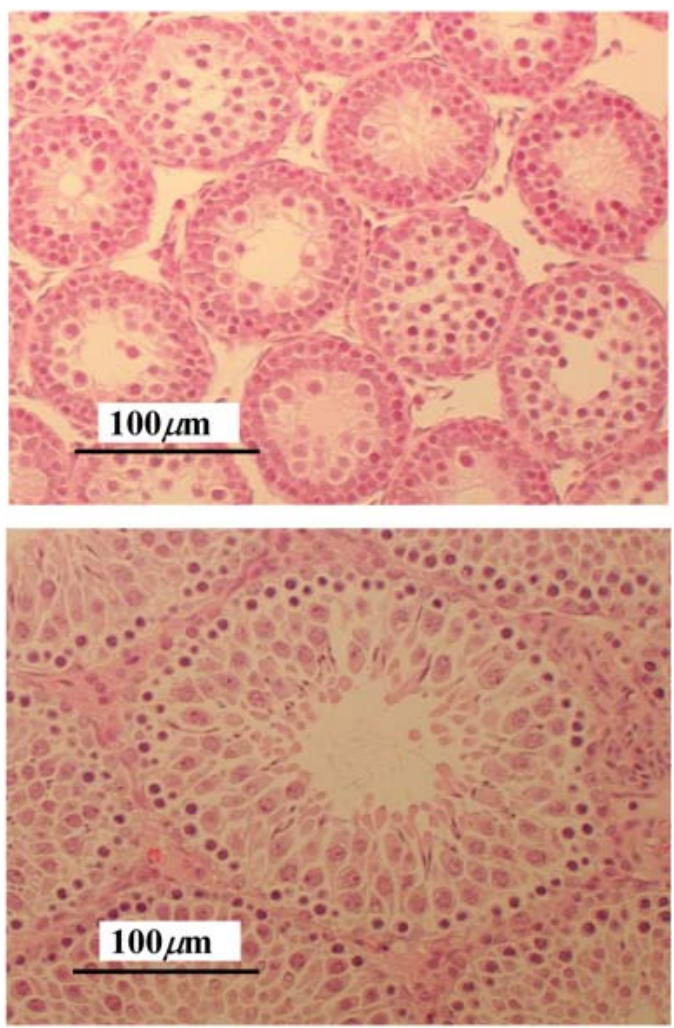

Fig. 1. Microscopic observation of seminiferous tubules in 17-day (17 D)- and 42-day-old (42 D) rats treated with TCDD and control group. The $42 \mathrm{D}$ seminiferous tubules correspond to stage XI. Bar $=100 \mu \mathrm{m}(\mathrm{H}-\mathrm{E}$ stain, $\times 132)$.

\section{Liver}

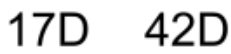

TCDD $(-)(+)(-)(+)$

\section{CYP1A1}

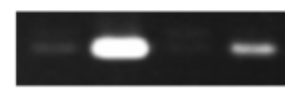

AhR

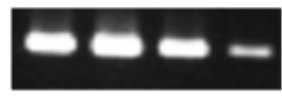

\section{ARNT}

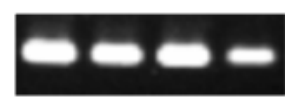

GAPDH
Testis
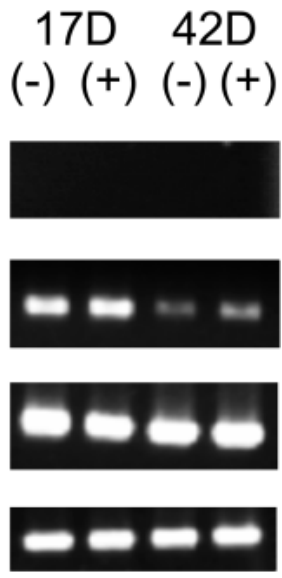

Fig. 2. Semi-quantitative analysis of the gene expression of CYP1A1, AhR and ARNT cDNA fragments, amplified by RTPCR, using testis and liver total RNA of 17-day (17 D)- and 42day-old (42 D) TCDD-treated $(+)$ and control $(-)$ rats as templates. GAPDH expression was used as an internal control. Images of ethidium bromide stained gel electrophoresis are shown.

germ cells between TCDD-treated and control animals. Moreover, expression of ER $\alpha$ was significantly increased in the testis of TCDD-treated rats at 17 days. These findings appear to suggest that unusual development of the testis is induced in TCDD-treated rats during the nursling period.

Many studies have reported that TCDD may cause not only anti-estrogenic effects but also possible estrogenic effects, such as induction of endometriosis $[10,27]$ and the progression of estrogen-dependent tumors $[3,5]$. The role played by TCDD in ER gene expression is not well known, however the interactions between ligand-activated AhR and ER have been investigated [36]. Ohtake et al. [22] recently reported that TCDD-activated AhR/ARNT heterodimer directly associated with $\mathrm{ER} \alpha$ and $\beta$, and the association resulted in the recruitment of unliganded ER and a co-activator for estrogen-responsive gene promoters, leading to activation of transcription and estrogenic effects. Their findings suggest that TCDD exerts estrogenic effects under the absence of estrogen, and anti-estrogenic effects under the presence of estrogen. We speculate that testicular growth was accelerated by weak estrogenic effects mediated by TCDD, since serum estrogen level is lower during the nursling period [18]. In human, pubertal growth is initiated by a small increase in estrogen concentration and estrogens promote skeletal construction during sexual maturation. It 
17D 42D
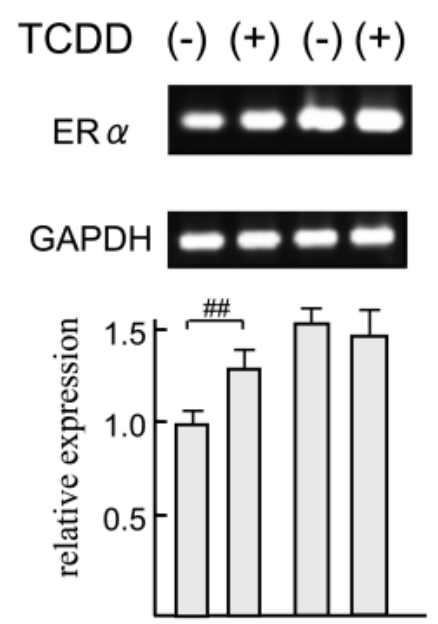

17D 42D

$(-)(+)(-)(+)$

$\operatorname{ER} \beta$

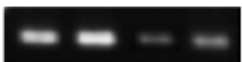

AR

$17 \mathrm{D} \quad 42 \mathrm{D}$

$(-)(+)(-)(+)$

\section{ER $\beta$}

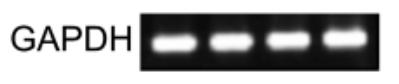

GAPDH
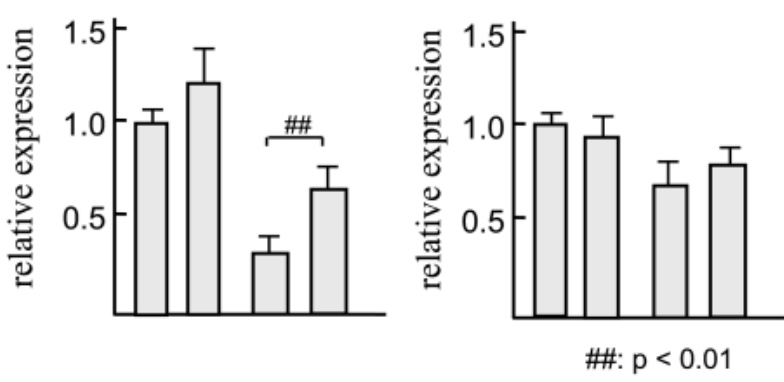

Fig. 3. Semi-quantitative analysis of the gene expression of $\operatorname{ER} \alpha, \operatorname{ER} \beta$ and AR cDNA fragments, amplified by RT-PCR, using testis total RNA of 17-day (17 D)- and 42-day-old (42 D) TCDD-treated (+) and control (-) rats as templates. GAPDH expression was used as an internal control. Relative expression is indicated as the ratio to GAPDH expression, and the value of the 17D (-) sample was determined as 1.0. Images of ethidium bromide stained gel electrophoresis are shown.

\section{$17 \mathrm{D}$ 42D \\ $17 \mathrm{D} \quad 42 \mathrm{D}$ \\ $17 \mathrm{D} \quad 42 \mathrm{D}$}

$\operatorname{TCDD}(-)(+)(-)(+)$

$(-)(+)(-)(+)$

$(-)(+)(-)(+)$

$\alpha$

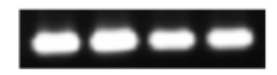

$\beta-A$

$-0$

$\beta-B$

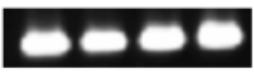

GAPDH
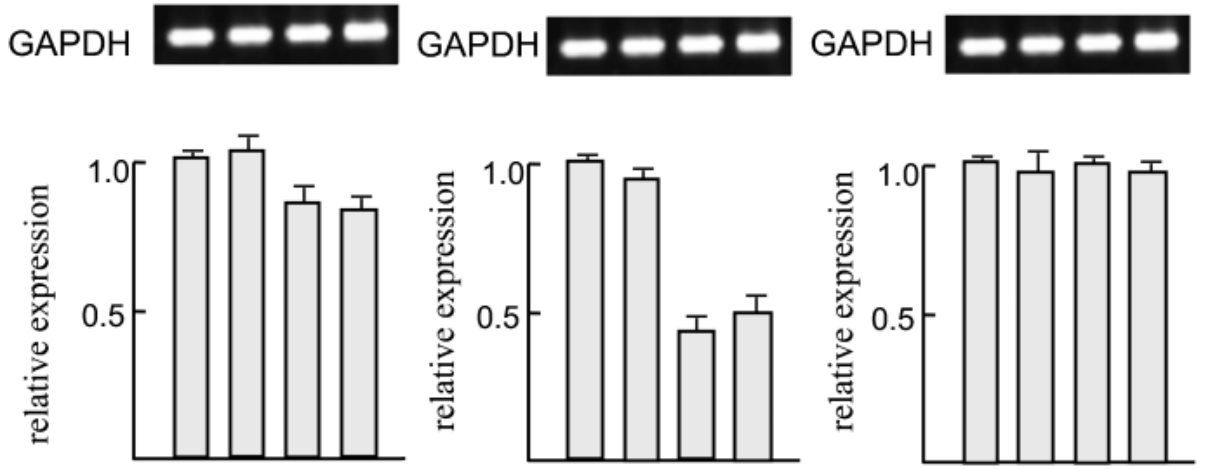

Fig. 4. Semi-quantitative analysis of the gene expression of inhibin subunits (inhibin $\alpha, \beta-\mathrm{A}$ and $\beta$-B) cDNA fragments amplified by RT-PCR, using testis total RNA of 17-day (17 D)- and 42-day-old (42 D) TCDD-treated (+) and control (-) rats as templates. GAPDH expression was used as an internal control. Relative expression is indicated as the ratio to GAPDH expression, and the value of the 17D (-) sample was determined as 1.0. Images of ethidium bromide stained gel electrophoresis are shown.

is believed that the weak estrogenic effect of TCDD under the absence of estrogen promote inappropriate testicular growth in premature male rats, and thereafter at 42 days, the anti-estrogenic effect of TCDD under the presence of estrogen and androgen retards skeletal and sexual maturation. Fukuzawa et al. [9] reported that TCDD administration significantly reduced the levels of $\mathrm{P} 450 \mathrm{scc}$ and luteinizing hor- mone $(\mathrm{LH})$ receptor in the adult mouse testis. This finding indicates that androgenic effects may be decreased at the time of sexual maturation, resulting in retarded testicular growth. Inhibin is synthesized in Sertoli cells and inhibits FSH synthesis in the pituitary. The expression of inhibin subunits and AR was not significantly changed by TCDD administration. 
These results show that the reproductive toxicity of TCDD relates mainly to the estrogen signaling pathway, hence the reason for upregulation of $\mathrm{ER} \beta$ expression in the 42-day-old TCDD-administered group. Taking these results together, we deduce that the estrogenic and anti-estrogenic effects mediated by low-dose TCDD are complicated and are exerted at various stages of sexual maturation.

In this study, we demonstrated that transplacental and lactational exposure of low-dose of TCDD affects testicular growth and ER gene expression of the testis in offspring. The expression of several genes, such as wings apart-like (WAPL) [14] and dioxin inducible factor-3 (DIF-3) [20], are regulated by TCDD administration. We can evaluate the effects of TCDD on the reproductive system by using these genes as expression standards.

ACKNOWLEDGEMENTS. This work was supported in part by grants from the Ministry of Education Japan, Culture Sports, Science and Technology, the Child Health Support Association, and the Education and Research Improvement and Promotion Program 2006 from the President of Tottori University.

\section{REFERENCES}

1. Bjerke, D.L. and Peterson, R.E. 1994. Reproductive toxicity of 2,3,7,8-tetrachlorodibenzo- $p$-dioxin in male rats: Different effects of in utero versus lactational exposure. Toxicol. Appl. Pharmacol. 127: 241-249.

2. Bjerke, D.L., Sommer, R.J., Moore, R.W. and Peterson, R.E. 1994. Effects of in utero and lactational 2,3,7,8-tetrachlorodibenzo- $p$-dioxin exposure on responsiveness of the male rat reproductive system to testosterone stimulation in adulthood. Toxicol. Appl. Pharmacol. 127: 250-257.

3. Brown, N.M., Manzolillo, P.A., Zhang, J.X., Wang, J. and Lamartiniere, C.A. 1998. Prenatal TCDD and predisposition to mammary cancer in the rat. Carcinogenesis 19: 1623-1629.

4. Chahoud, I., Krowke, R., Schimmel, A., Merker, H.J. and Neubert, D. 1989. Reproductive toxicity and pharmacokinetics of 2,3,7,8-tetrachlorodibenzo- $p$-dioxin: 1 . Effects of high doses on the fertility of male rats. Arch. Toxicol. 63: 432-439.

5. Davis, B.J., Mccurdy, E.A., Miller, B.D., Lucier, G.W. and Tritscher, A.M. 2000. Ovarian tumors in rats induced by chronic 2,3,7,8-tetrachlorodibenzo- $p$-dioxin treatment. Cancer Res. 60: 5414-5419.

6. Faqi, A.S., Dalsenter, P.R., Merker, H.J. and Chahound, I. 1998. Reproductive toxicity and tissue concentrations of low doses of 2,3,7,8-tetrachlorodibenzo- $p$-dioxin in male offspring rats exposed throughout pregnancy and lactation. Toxicol. Appl. Pharmacol. 150: 383-392.

7. Fernandez-Salguero, P.M., Hilbert, D.M., Rudikoff, S., Ward, J.M. and Gonzalez, F.J. 1996. Aryl-hydrocarbon receptor-deficient mice are resistant to 2,3,7,8-tetrachlorodibenzo- $p$-dioxininduced toxicity. Toxicol. Appl. Pharmacol. 140: 173-179.

8. Franc, M.A., Pohjanvirta, R., Tuomisto, J. and Okey, A.B. 2001. Persistent low-dose 2,3,7,8-tetrachlorodibenzo- $p$-dioxin exposure: Effect on aryl hydrocarbon receptor expression in a dioxin-resistance model. Toxicol. Appl. Pharmacol. 175: 4353 .

9. Fukuzawa, N.H., Ohsako, S., Wu, Q., Sakaue, M., Fujii-
Kuriyama, Y., Baba, T. and Tohyama, C. 2004. Testicular cytochrome P450scc and LHR as possible targets of 2,3,7,8tetrachlorodibenzo- $p$-dioxin (TCDD) in the mouse. Mol. Cell Endocrinol. 221: 87-96.

10. Gibbons, A. 1993. Dioxin tied to endometriosis. Science 262: 1373.

11. Gray, L.E. Jr., Kelce, W.R., Monosson, E., Ostby, J.S. and Birnbaum, L.S. 1995. Exposure to TCDD during development permanently alters reproductive function in male Long Evans rats and hamsters: Reduced ejaculated and epididymal sperm numbers and sex accessory gland weights in offspring with normal androgenic status. Toxicol. Appl. Pharmacol. 131: 108118.

12. Ikeda, M., Tamura, M., Yamashita, J., Suzuki, C. and Tomita, T. 2005. Repeated in utero and lactational 2,3,7,8-tetrachlorodibenzo- $p$-dioxin exposure affects male gonads in offspring, leading to sex ratio changes in F2 progeny. Toxicol. Appl. Pharmacol. 206: 351-355.

13. Ishizuka, M., Yonemoto, J., Zaha, H., Tohyama, C. and Sone, H. 2003. Perinatal exposure to low doses of 2,3,7,8-tetrachlorodibenzo- $p$-dioxin alters sex-dependent expression of hepatic CYP2C11. J. Biochem. Mol. Toxicol. 17: 278-285.

14. Kuroda, M., Oikawa, K., Ohbayashi, T., Yoshida, K., Yamada, K., Mimura, J., Matsuda, Y., Fujii-Kuriyama, Y. and Mukai, K. 2005. A dioxin sensitive gene, mammalian WAPL, is implicated in spermatogenesis. FEBS Lett. 579: 167-172.

15. Lahvis, G.P. and Bradfield, C.A. 1998. Ahr null alleles: Distinctive or different? Biochem. Pharmacol. 56: 781-787.

16. Mably, T.A., Bjerke, D.L., Moore, R.W., Gendron-Fitzpatrick, A. and Peterson, R.E. 1992. In utero and lactational exposure of male rats to 2,3,7,8-tetrachlorodibenzo- $p$-dioxin. 3 . Effects on spermatogenesis and reproductive capability. Toxicol. Appl. Pharmacol. 114: 118-126.

17. Mably, T.A., Moore, R.W. and Peterson, R.E. 1992. In utero and lactational exposure of male rats to 2,3,7,8-tetrachlorodibenzo-p-dioxin. 1. Effects on androgenic status. Toxicol. Appl. Pharmacol. 114: 97-107.

18. Marcus, R. and Korenman, S.G. 1976. Estrogens and the human male. Annu. Rev. Med. 27: 357-370.

19. Nishimura, N., Yonemoto, J., Nishimura, H., Ikushiro, S. and Tohyama, C. 2005. Disruption of thyroid hormone homeostasis at weaning of Holtzman rats by lactational but not in utero exposure to 2,3,7,8-tetrachlorodibenzo-p-dioxin. Toxicol. Sci. 85: 607-614.

20. Ohbayashi, T., Oikawa, K., Iwata, R., Kameta, A., Evine, K., Isobe, T., Matsuda, Y., Mimura, J., Fujii-Kuriyama, Y., Kuroda, M. and Mukai, K. 2001. Dioxin induces a novel nuclear factor, DIF-3, that is implicated in spermatogenesis. FEBS Lett. 508: 341-344.

21. Ohsako, S., Miyabara, Y., Nishimura, N., Kurosawa, S., Sakaue, M., Ishimura, R., Sato, M., Takeda, K., Aoki, Y., Sone, H., Tohyama, C. and Yonemoto, J. 2001. Maternal exposure to a low dose of 2,3,7,8-tetrachlorodibenzo- $p$-dioxin (TCDD) suppressed the development of reproductive organs of male rats: Dose-dependent increase of mRNA level of $5 \alpha-$ reductase type 2 in contrast to decrease of androgen receptor in the pubertal ventral prostate. Toxicol. Sci. 60: 132-143.

22. Ohtake, F., Takeyama, K., Matsumoto, T., Kitagawa, H., Yamamoto, Y., Nohara, K., Tohyama, C., Krust, A., Mimura, J., Chambon, P., Yanagisawa, J., Fujii-Kuriyama, Y. and Kato, S. 2003. Modulation of oestrogen receptor signaling by association with the activated dioxin receptor. Nature 423: 545-550.

23. Ohyama, K., Iwatani, N., Nakagomi, Y., Ohta, M., Shimura, 
Y., Sano, T., Sato, K., Ohno, R., Mabe, H., Ishikawa, H. and Nakazawa, S. 1999. Growth hormone advances spermatogenesis in premature rats treated with gonadotropin-releasing hormone agonist. Endocr. J. 46: 555-562.

24. Okey, A.B., Riddick, D.S. and Harper, P.A. 1994. The Ah receptor: Mediator of the toxicity of 2,3,7,8-tetrachlorodibenzo- $p$-dioxin (TCDD) and related compounds. Toxicol. Lett. 70: $1-22$.

25. Peterson, R.E., Theobald, H.M. and Kimmel, G.L. 1993. Developmental and reproductive toxicity of dioxins and related compounds: Cross-species comparisons. Crit. Rev. Toxicol. 23: 283-335.

26. Poland, A., Palen, D. and Glover, E. 1994. Analysis of the four alleles of the murine aryl hydrocarbon receptor. Mol. Pharmacol. 46: 915-921.

27. Rier, S. and Foster, W.G. 2002. Environmental dioxins and endometriosis. Toxicol. Sci. 70: 161-170.

28. Roman, B.L. and Peterson, R.E. 1998. In utero and lactational exposure of the male rat to 2,3,7,8-tetrachlorodibenzo- $p$-dioxin impairs prostate development. 1. Effects on gene expression. Toxicol. Appl. Pharmacol. 150: 240-253.

29. Satoh, K., Ohyama, K., Nakagomi, Y., Ohta, M., Shimura, Y., Sano, T., Ishikawa, H., Amemiya, S. and Nakazawa, S. 2002. Effects of growth hormone on testicular dysfunction induced by cyclophosphamide (CP) in GH-deficient rats. Endocr. J. 49: 611-619.

30. Schultz, R., Suominen, J., Varre, T., Hakovirta, H., Parvinen,
M., Toppari, J. and Pelto-Huikko, M. 2003. Expression of aryl hydrocarbon receptor and aryl hydrocarbon receptor nuclear translocator messenger ribonucleic acids and proteins in rat and human testis. Endocrinology 144: 767-776.

31. Sloop, T.C. and Lucier, G.W. 1987. Dose-dependent elevation of Ah receptor binding by TCDD in rat liver. Toxicol. Appl. Pharmacol. 88: 329-337.

32. Sommer, R.J., Ippolito, D.L. and Peterson, R.E. 1996. In utero and lactational exposure of male Holtzman rat to 2,3,7,8-tetrachlorodibenzo- $p$-dioxin: Decreased epididymal and ejaculated sperm numbers without alterations in sperm transit rate. Toxicol. Appl. Pharmacol. 140: 146-153.

33. Weber, L.W., Ernst, S.W., Stahl, B.U. and Rozman, K. 1993. Tissue distribution and toxicokinetics of 2,3,7,8-tetrachlorodibenzo- $p$-dioxin in rats after intravenous injection. Fundam. Appl. Toxicol. 21: 523-534.

34. Whitlock, J.P. Jr. 1999. Induction of cytochrome P450 1A1. Annu. Rev. Pharmacol. Toxicol. 39: 103-125.

35. Wilker, C., Johnson, L. and Safe, S. 1996. Effects of developmental exposure to indole-3-carbinol or 2,3,7,8-tetrachlorodibenzo- $p$-dioxin on reproductive potential of male offspring. Toxicol. Appl. Pharmacol. 141: 68-75.

36. Wormke, M., Stoner, M., Saville, B., Walker, K., Abdelrahim, M., Burghardt, R. and Safe, S. 2003. The aryl hydrocarbon receptor mediates degradation of estrogen receptor $\alpha$ through activation of proteasomes. Mol. Cell Biol. 23: 1843-1855. 